\title{
3D Resistivity Data Modelling to Identify Aquifer Geometry by Qualitative Analysis (Field Study: PDAM Surabaya Groundwater Conservation Area, Pasuruan)
}

\author{
Ayi Syaeful Bahri, Amien Widodo, Widya Utama, Dwa Desa Warnana, Pegri Rohmat Aripin, Adib \\ Banuboro, Robi Alfaq Abdillah \\ Department of Geophysical Engineering, FTSP, Sepuluh Nopember Institute of Technology Surabaya Jl. Arief
}

Rahman Hakim, Surabaya 60111

\begin{abstract}
The resistivity method is one of the geophysical methods used to identify the aquifer layer by utilizing the rock response to the flow of electric current. This method considered more effective and can give a good subsurface cross-section, especially the fluid response. In this research, 3D modelling for identify geometry of subsurface geological structures of this study focus in three area (Plintahan, Duren Sewu, and Karangjati) using 2D resistivity data. Data Measurement of 2D resistivity using Wenner-Schlumberger configuration with length of each line is $\mathbf{1 5 5}$ meters and the target depth is $\mathbf{3 0}$ meters. The purpose of this configuration is to get an inverse with a resolution that is good to the lateral and vertical. The results show that the types of rocks in the research area was clay, sand and sandy shale with resistivity value 50-150 ohmmeter where sand rocks interpreted as aquifer rocks at depths of 2-7 meters and a thickness of 2-5 meters. The result of the resulting 3D modelling showed that the aquifer layer in Plintahan area showed the geological continuity with anticline geometry, in another area the aquifer layer in Durensewu - Karang Jati area showed the aquifer geometry prediction but there is no continuity of the structure of each other.
\end{abstract}

Keywords - Resistivity Method, Wenner-Schlumberger Configuration, Pemeability, Aquifer, Groundwater

\section{INTRODUCTION}

$\mathrm{W}$ ater supplies of Surabaya city are generated from river area that mainly comes from the Brantas River, but these city also has another water reserve in subsurface or groundwater. Groundwater is a moving water which is in high porosity medium of soil that seep into the soil and combine to form a soil layer called the aquifer (Herlambang, 1996).

The Groundwater supplies of Surabaya has manifestation that shown by 17 springs located in Pasuruan. To enhance the quality and quantity of water supplies in Surabaya especially from groundwater reserve, it needs a subsurface mapping of aquifer by using geophysical survey. This survey to determine the existence of aquifers, distribution and location.

In addition, a geophysical survey also can help us to make a plan for the exploitation activity and does not interfere the equilibrium between the discharge area (area removable) and recharge area (local charge) by looking for the distribution of aquifer in the subsurface.

One of the geophysical methods that can be used to determine ground water aquifers is the resistivity method. This method can describe the subsurface structure based on electrical characteristics of subsurface layer.

In this research use 2D resistivity method. Based on the 2D resistivity data, 3D modelling can make by crosssection of 2D resistivity data. The result of 3D modelling is expected to be able to show the geometry prediction from geology structure of aquifer. Survey area in this research only focus on three areas (Plintahan, Duren Sewu, and Karangjati) that were located in Pasuruan district. Therefore, this research can be used as a reference to the next research for calculate the estimation of reserves, so it can be planned long-term exploitation activities by considering the geometry of the aquifer through a 3D approach. Thus, this research can support the conservation of groundwater program in three areas in order to maintained aquifer for long periods of time.

\subsection{Geology of Research Areas}

Pasuruan City is located in the central of Pasuruan district, between $112^{\circ} 45^{\prime}-112^{\circ} 55^{\prime}$ East and $7^{\circ} 35^{\prime}-7^{\circ}$ $45^{\prime}$ South Latitude. This area is a lowland with 4 meters average height above sea level.

Geological of Pasuruan region consist of alluvium (mud) with its intermediate to slightly bases nature. Pasuruan has a flat area that ran from South to North with a slope of $0-1 \%$ and a height of $0-4$ meters above sea level. For the North, there are parts of slightly basin structure so that the drainage is inhibited.

Stratigraphy of the research area consists of ArjunaWelirang Volcano Rock, which consists of:

\section{a) Breccia volcano}

Colored brown - yellow cloudy, medium-alkaline; Sandsized bombs, angled-rounded responsibilities; Most fragments of andesite, basalt, sandstone, obsidian, mafic minerals and volcano glass with masadasar tuf pasiran; Slightly incompressible, less solid, open pack.

\section{b) Lava}

Gray, black, reddish-brown and greenish; Arranged andesit - basal; Generally composed of feldspar, pyroxene, bright mineral, minerals mafic or ore and hornblende; Local porphyry, bervicular on its surface forming a pattern like bread crust; Stretched, flow structured or like a tongue insert in the breccias.

\section{c) Breccia tufan}

Colored turbid, brown gray and reddish; Moderate, less compact, easy to get off, a little repih; Grained coarse sand - bombs, cornered responsibility, bomb-sized components spread unevenly; Andesite, basal, obsidian, 
August $1^{\text {st }}-2^{\text {nd }}$ 2017, Surabaya - Indonesia

volcanic, porphyry, volcanic glass and black minerals, based on tar tar; Structured coatings, streams and local crosses.

\section{d) Tuff}

Dark white, light brown gray; Grained coarse sand until smooth, slightly incompressible, locally there are uniformly dispersed layell-sized rock fragments; With many bright minerals, a little bit of sandstone, and glass or volcanic ash.

\subsection{Geoelectrical Method}

Geoelectrical is one of the geophysical methods for invasion of subsurface layer, the principle of this method is generated by DC current (Direct Current) into the subsurface and record the electrical potential caused by current flow in the surface, resistant changes from calculation by ohm law describe the subsurface layers. Enhancement of the ion concentration in the fluid will increase the fluid conductivity and decrease the rock resistance value (Hasanuddin and Pryambodo, 2009). There are two kind of geoelectric methods that are an active and a passive method. In this research, authors more quickly, using this method then the depth of the material sought to be detected by a prediction. The working principle of this method is to inject electric current (I) into the soil and to measure the differential electrical potential $(\mathrm{V})$ response from the material below the soil surface vertically.

The basic principle of the measurement of 2D resistivity (lateral mapping) is flow of electric current from the surface by generate high voltage into the earth by using electrode configuration in survey area, we got a value of electrical potential $(\mathrm{mV})$ due to the currents flow in medium earth that has a resistance value (Ohm) will be obtained from the device while measurement. In resisitivity measurement, it is assumed that the earth has an isotropic homogeneous medium, but in the earth's real field is composed from different materials per layer, therefore, the value of resistivity measurement is a pseudo-resistivity that depends on the configurations in the measurement.

Wenner-schlumberger configuration was used in this reasearch. This configuration has a ratio of the distance between the C1-P1 electrodes and the space between P1$\mathrm{P} 2$ at $\mathrm{n}$. If the distance P1-P2 is a, then the distance $\mathrm{C} 1$ -

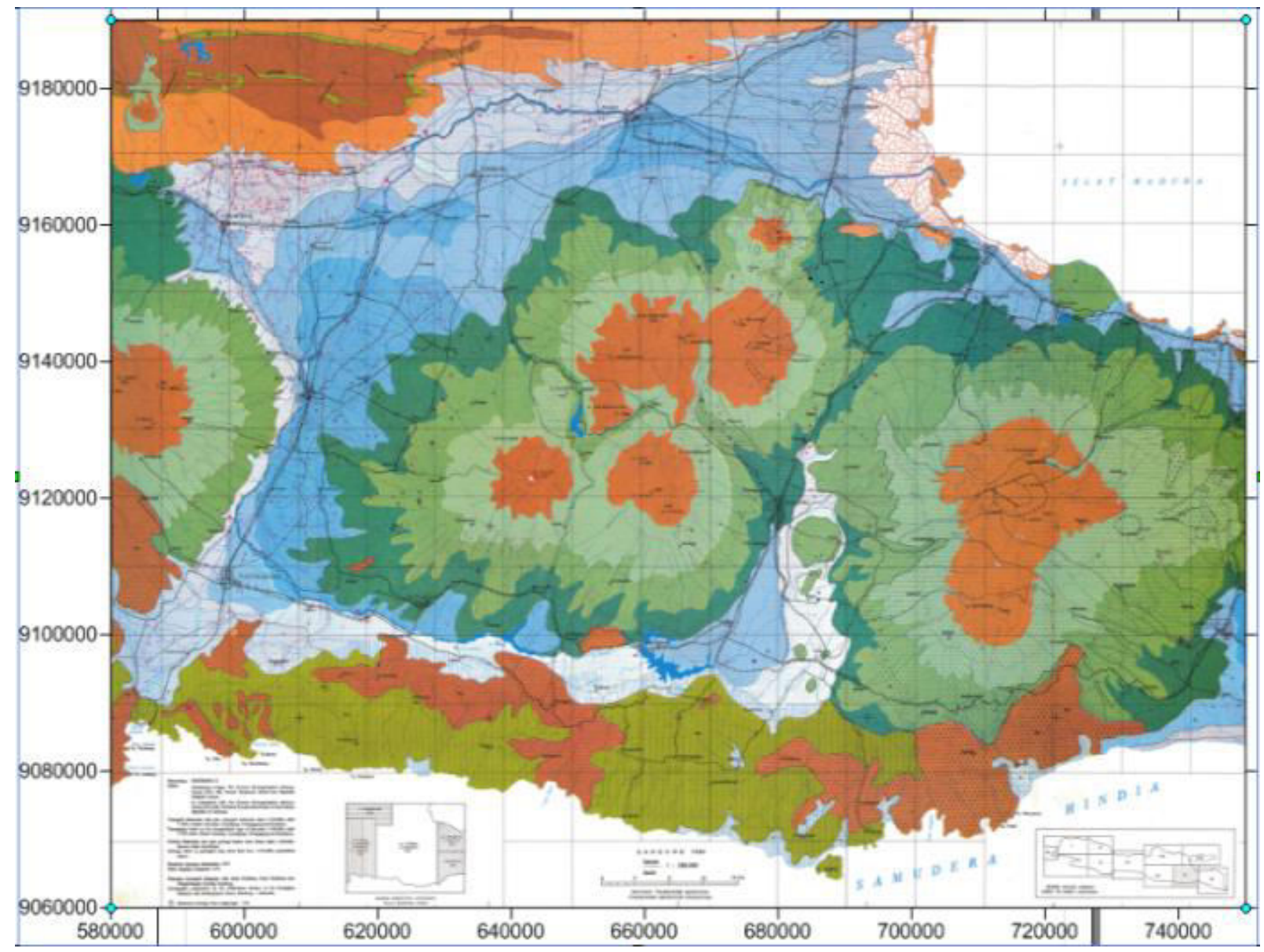

Figure 1. Map of Hidrogeologi Pasuruan.

used an active method. It called resistivity method consist of Vertical electrical sounding (1D Resistivity Methods) and 2D resistivity lateral mapping method.

Vertical geoelectric sounding method (1D) can be an alternative for drilling method with a ratio lower cost and
$\mathrm{P} 1$ is (na). 


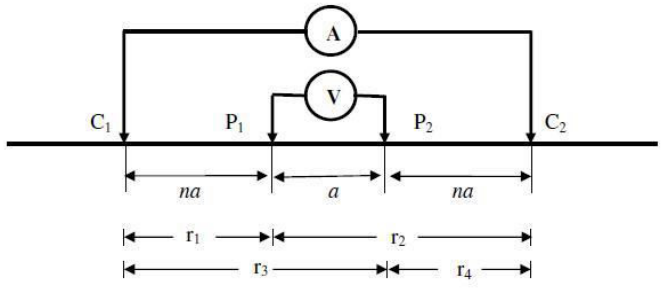

Figure 2. Configuration Form Wenner-Schlumberger

The geometry factor value $(\mathrm{k})$ in this configuration can be determined by use these equation below :

$$
k=\pi n(n+1) a
$$

\subsection{Material Resistivity}

Much minerals make some bad characteristic conductivity of rocks even though some of the original metal and graphite can conduct electricity. The resistivity measurement of the earth's material is primarily determined by the movement of the mutant ions in the pores of the fluid. Here is the variation of earth material resistivity.

\begin{tabular}{|cc|}
$\begin{array}{c}\text { Table 1. Earth material resistivity values (Telford et al, 1990) } \\
\text { Material }\end{array}$ & $\begin{array}{c}\text { Resistivity (Ohm-meter) } \\
\text { Air }\end{array}$ \\
\hline Pirit & $0.01-100$ \\
\hline Quartz & $500-800,000$ \\
\hline Calcite & $1 \times 10^{12-1} \times 10^{13}$ \\
\hline Rock salt & $30-1 \times 10^{13}$ \\
\hline Granite & $200-100,000$ \\
\hline Andesite & $1.7 \times 10^{2-45} \times 10^{4}$ \\
\hline Basal & $200-100,000$ \\
\hline Gamping & $5000-10,000$ \\
\hline Sandstone & $200-8,000$ \\
\hline Slate & $20-2,000$ \\
\hline Sand & $1-1,000$ \\
\hline Clay & $1-100$ \\
\hline Groundwater & $0.5-300$ \\
\hline Sea water & 0.2 \\
\hline Dry pebbles & $600-10,000$ \\
\hline Alluvium & $10-800$ \\
\hline
\end{tabular}

\section{METHOD}

The location of the research is located in three spring areas: Plintahan, Karang Jati, and Duren Sewu as shown in the figure 11 and figure 12 .

In this study has a purpose to determine the approximate geometry of subsurface geological structure which indicated the aquifer below the springs. In order to get information about the model or the shape of the aquifer. In general, the research flow can be described in the following diagram.

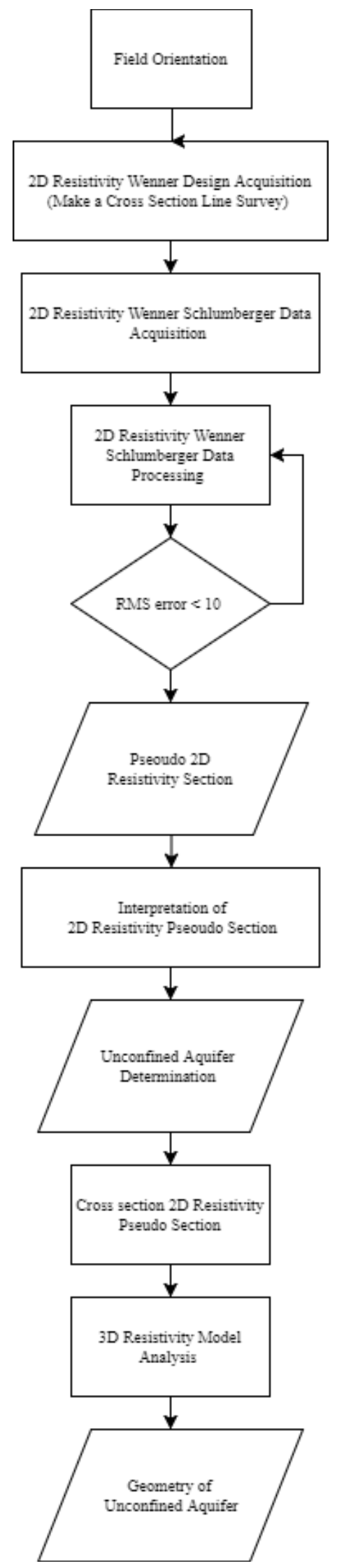

Figure 3. Workflow 


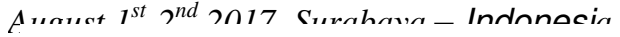

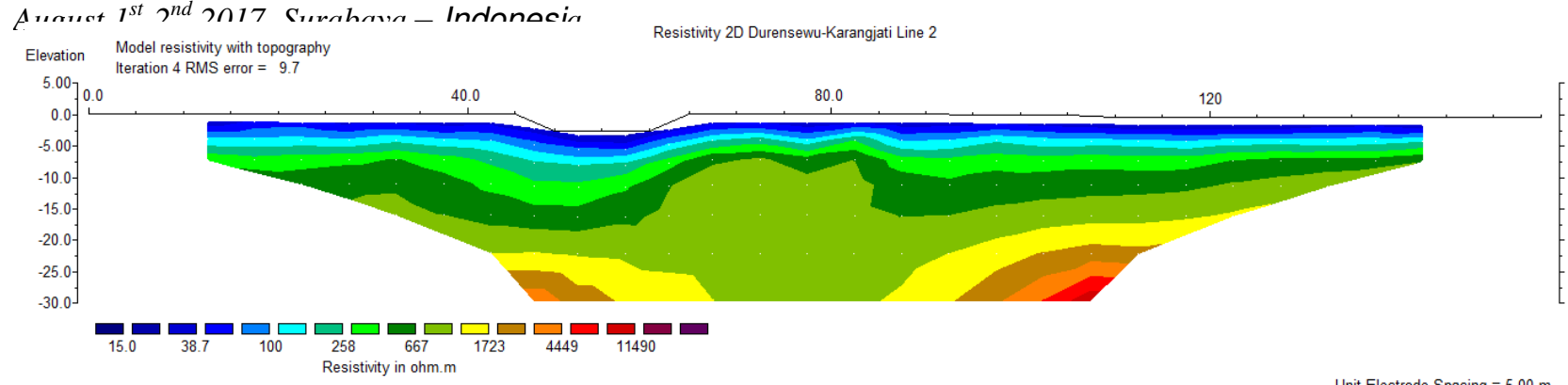

Horizontal scale is 41.45 pixels per unit spacing

Vertical exaggeration in model section display $=0.66$

Unit Electrode Spacing $=5.00 \mathrm{~m}$.

First electrode is located at $0.0 \mathrm{~m}$.

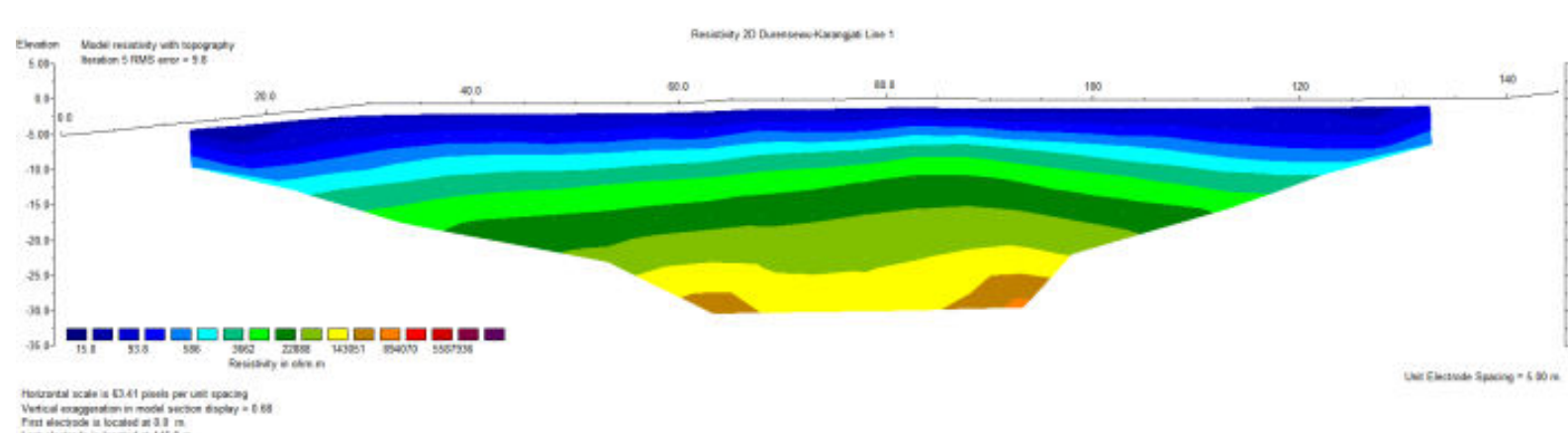

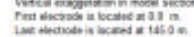

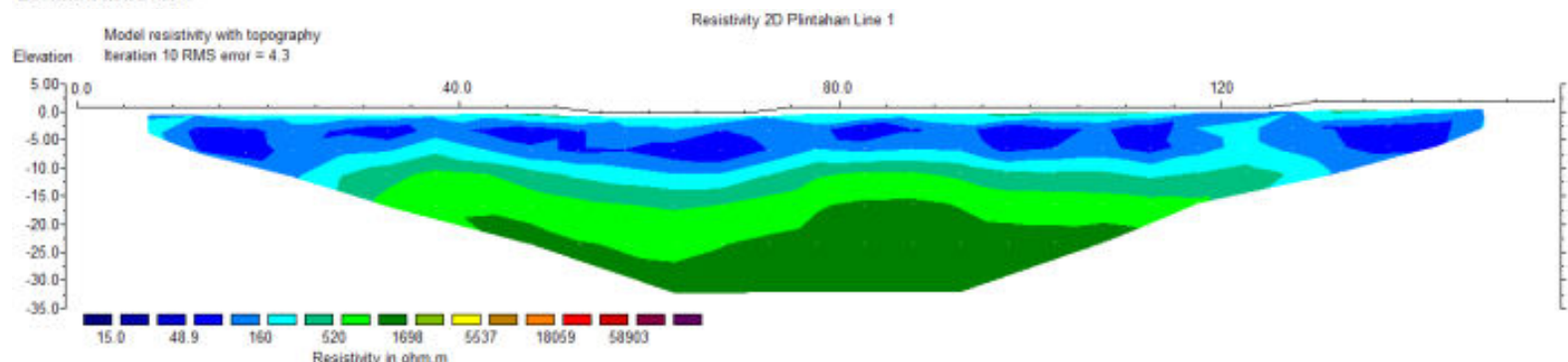

Urit Elactrode Spacing $=500 \mathrm{~m}$

Herizontal scale is 41.45 piosals per unt specing

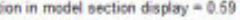

Fint tiectrode is located at $0.0 \mathrm{~m}$
Leat elictrode is located of $155.0 \mathrm{~m}$

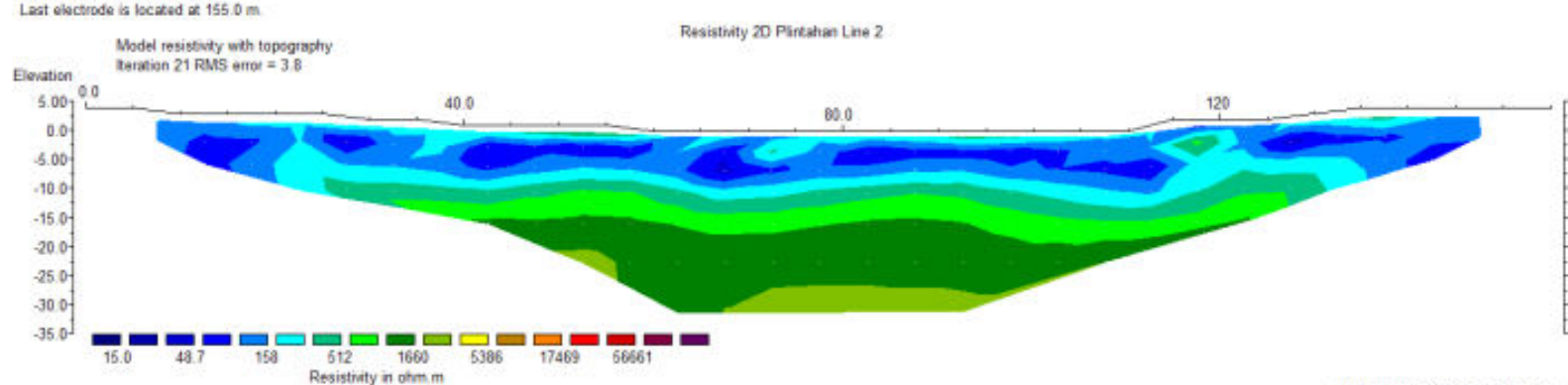

Morizortal scale is 41.42 pxess per urit spacing

Vortical exszgerstion in modal section displey $=0.61$

Uhe Electrode Specing $=500 \mathrm{~m}$

Frat einctrode is locited $x 00 \mathrm{~m}$.

Figure 5. Results of Layer Interpretation on Resistivity Sections at Plintahan Location; a. First line and b. Second line.

\section{RESULTS AND DISCUSSION}

When associated with regional geology the hydrogeology or groundwater surface of the investigation area is related to rock conditions formed around this area. Hydrogeological conditions, generally closely related to certain aquifer systems.
Based on the Hydrogeological Map, the presence of groundwater and aquifers of the inquiry area enter into the flow aquifer system through the intercellular spaces and spaces with high productive aquifer conditions with wide spread (aquifers with varying degrees of depth and groundwater depth). 


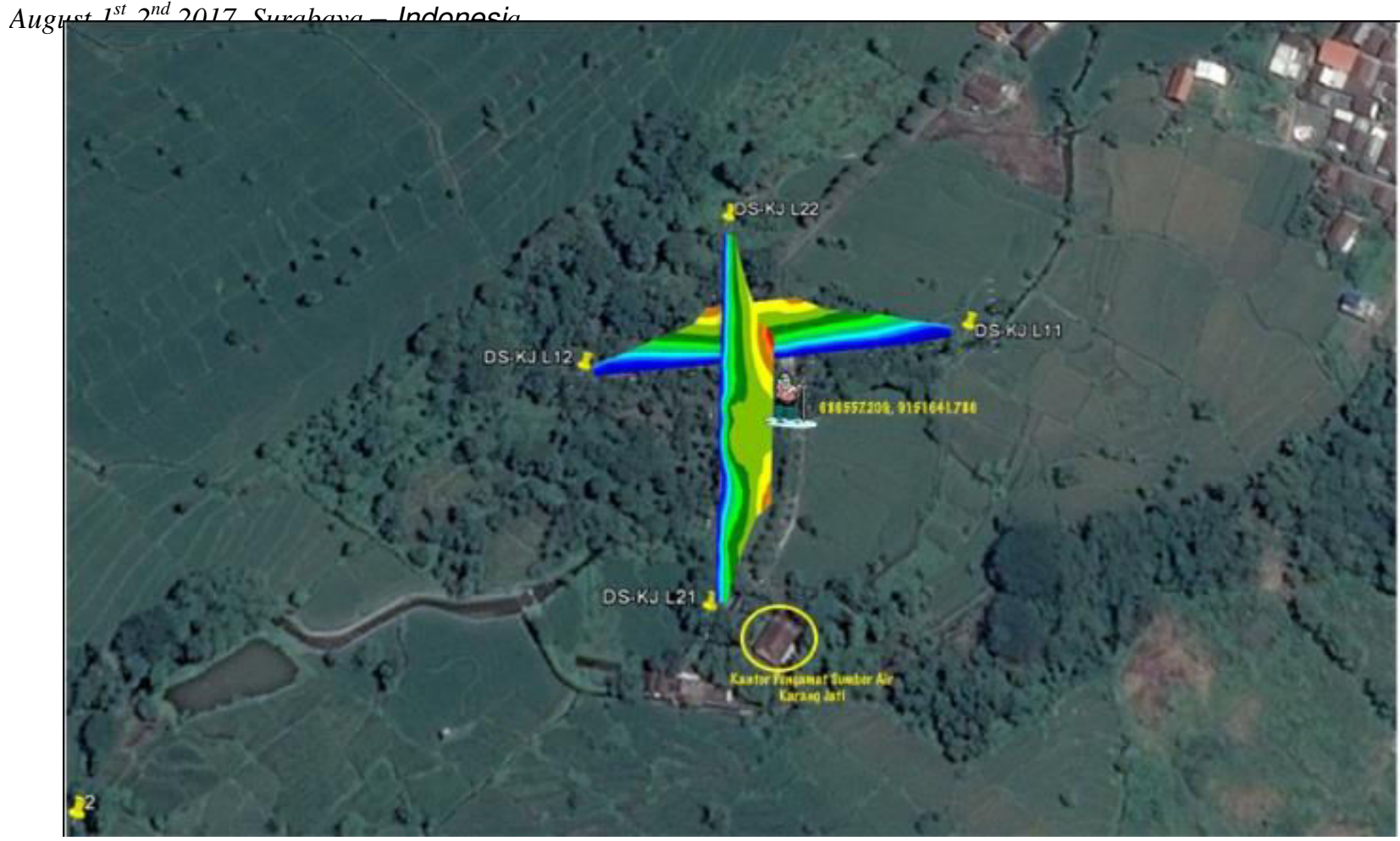

Figure 6. Overlay 2D Model Results with Real Condition of Duren Sewu-Karang Jati.

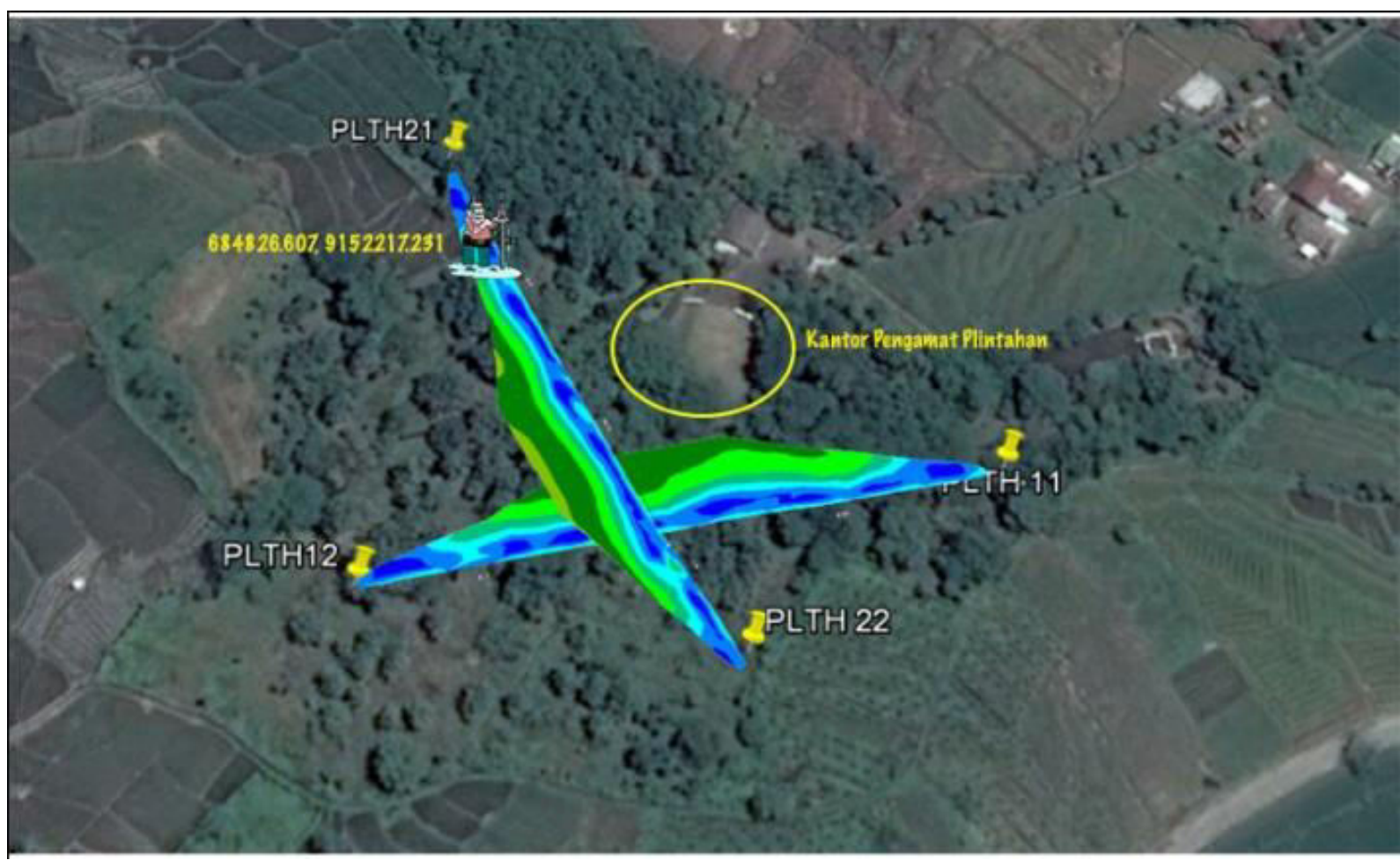

Figure 7. Overlay 2D Model Result with Real Condition of Plintahan.

The research area's lithology is included in two formations, Arjuna-Wilerang Volcano Formation and Rabano Tuff Formation consist of Arjuna-Wilerang volcanic polymic breccia, tuffan Rabano sandstone and alluvial sediment units. In Arjuna-Wilerang volcanic polymic breccia units and tuffan sandstone units Rabano has a different facies stratigraphic relationship and in units of alluvial deposits are not aligned in the tuffan sandstone unit of Rabano.

Based on the lithologic conditions, the hydrogeological parameters, the lithology capability and the existence of underground water, in the study area there is one type of aquifer, the aquifer with groundwater flow through the inter space. In the aquifer with groundwater flow through inter grain space has tufan sandstone lithology, polymic breccia , and conglomerate sandstones.

\subsection{D Resistivity}

As described in the research methodology, resistivity data acquisition of the Wenner-Schlumberger configuration type is performed at 4 locations in the research area. Processing and interpretation of the data 
The Third International Conference on Civil Engineering Research (ICCER)

August $1^{\text {st }}-2^{\text {nd }} 2017$, Surabaya - Indonesia

are finish directly in the 4 locations into 3 -dimensional model.

For the sand layer as an aquifer (volcanic fan area) has interpreted has a resistivity value between $50-150$ Ohmmeter. In the figure 5, the sand layer is shown in color ( $\square$ and $\square$ ), In the color band at the 3 and 4 from the left which has a resistivity value of about 93.8 Ohmmeter in line 1 and 100 Ohmemetr tracks in line two. So that, we can identify from the 2D model the aquifer is located at depth of 3-7 meters with a reservoir thickness about 3-5 meters and has lithology of sand rocks.

In the Plintahan area shown in the Figure 6 the sand layer is shown in color ( $\square$ and $)$. In the color scale at number 4 and 5 from the left which has a resistivity value about 104.45 Ohmmeter in line 1 and 103.35 Ohmmeter in line 2. So from the 2D model the aquifer is located at a depth of 1.5-3 meters with a reservoir thickness of about 5-10 meters with sand rocks as an aquifer.

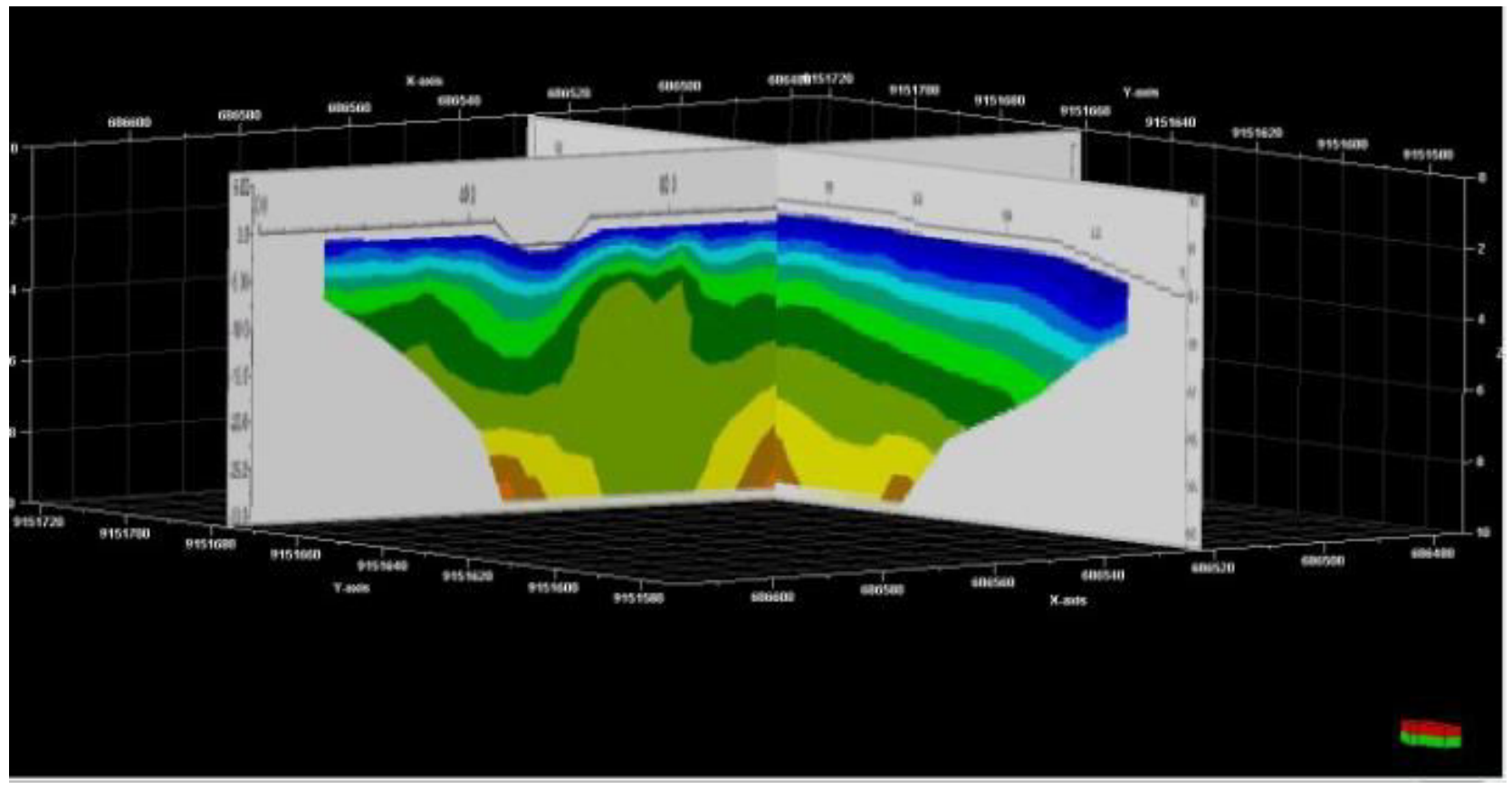

Figure 8. Cross section 2D resistivity in Durensewu-Karangjati

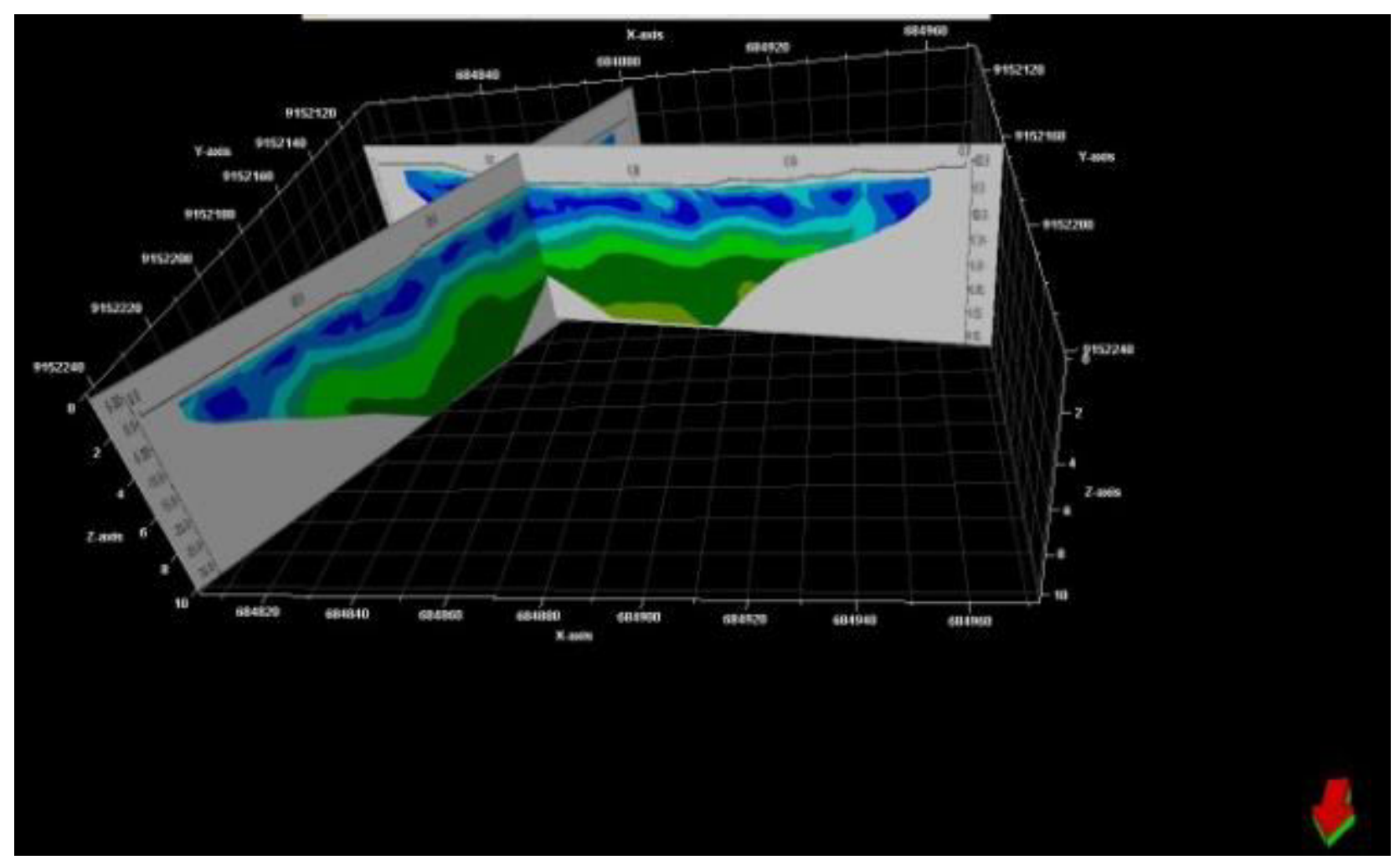




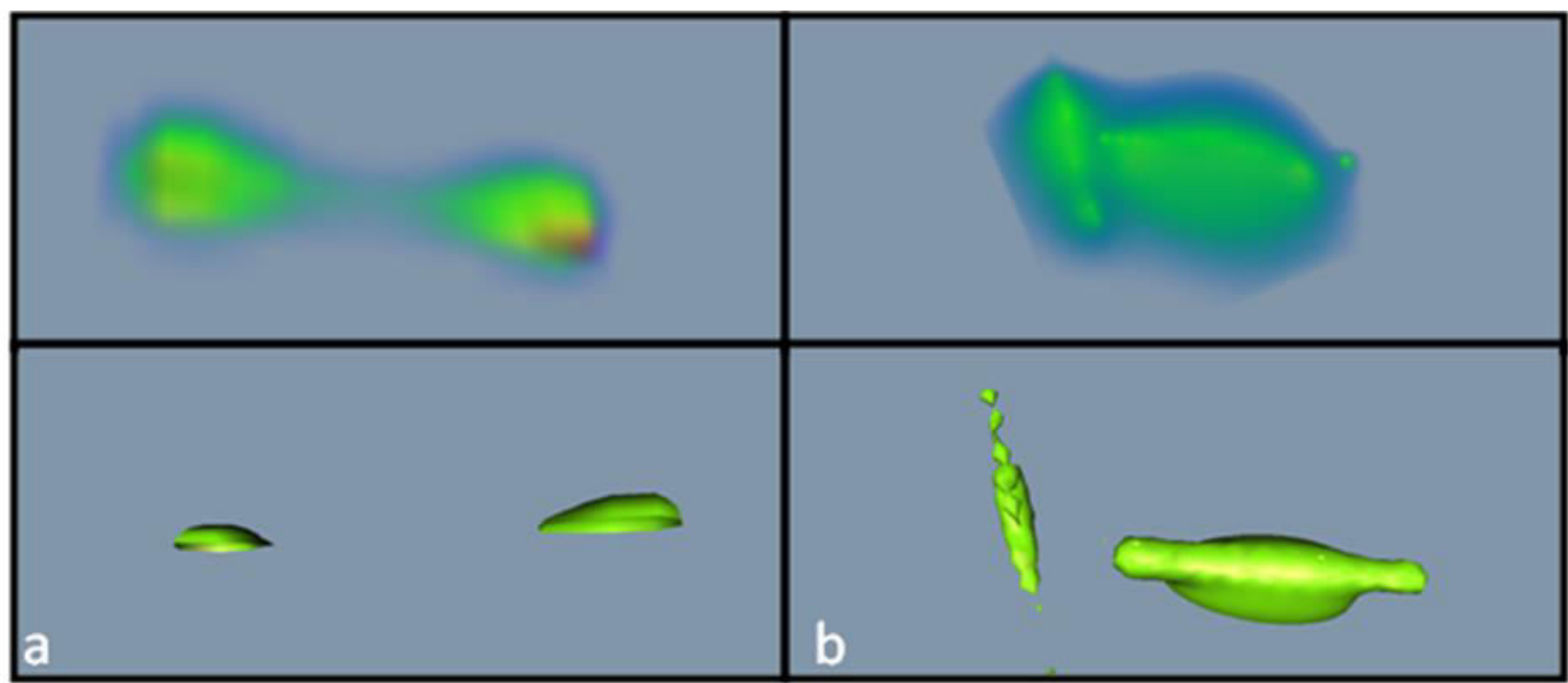

Figure 10. Results of aquifer 3D modelling based on 2D resistivity cross-section in (a) Durensewu-Karangjatii and (b) Plintahan

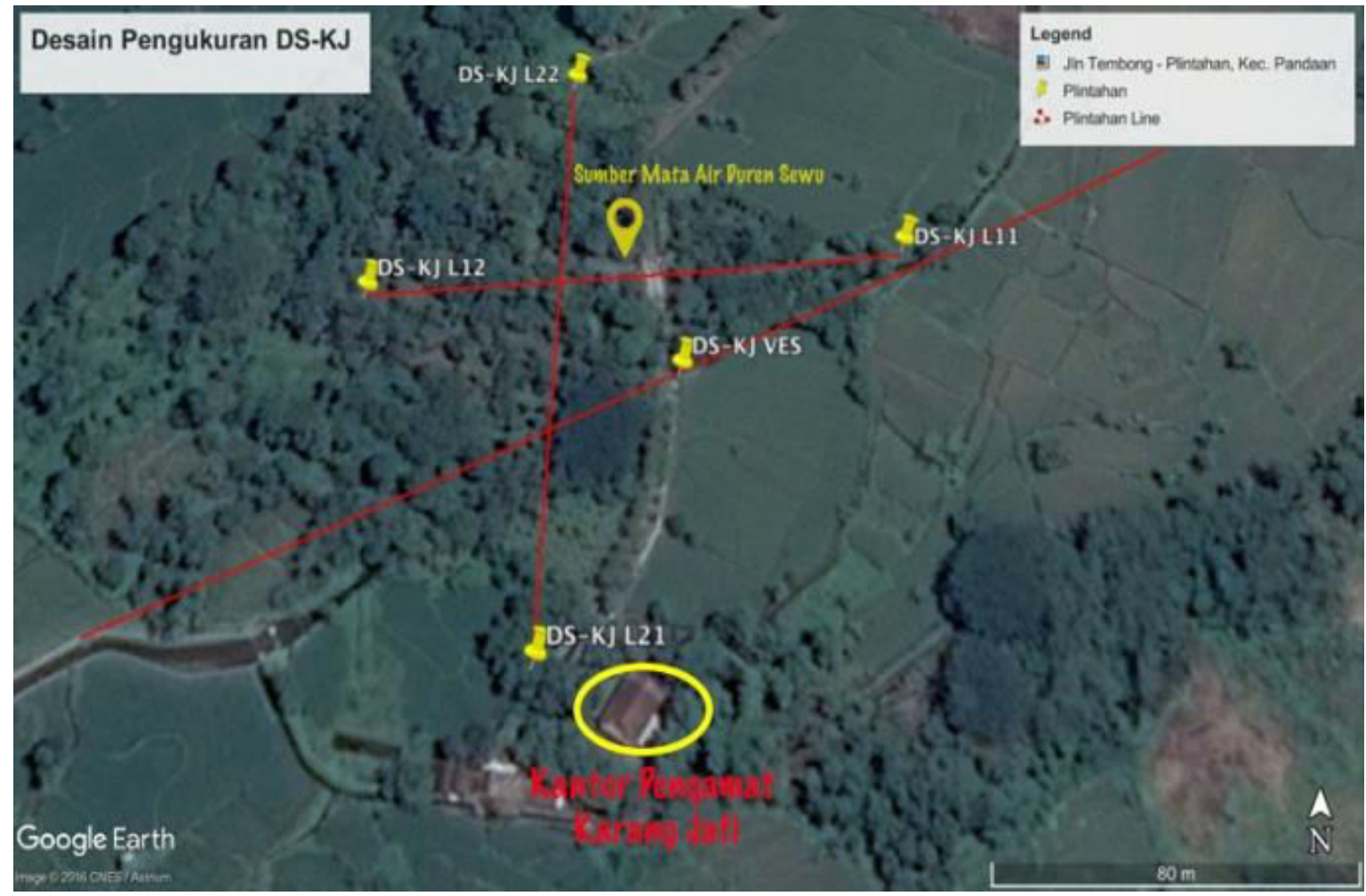

Figure 11. 2D and 1D Measurement Design at Duren Sewu-Karang Jati

From the result above, a layer that identified as aquifer is given a blue highlight with a depth of 5 meters to 10 meters and a thickness of 2 to 5 meters. That layer is indicated with a resistivity value of $32 \mathrm{ohmm}$ to 142 ohmm which is interpreted as a sand layer. Aquifer obtained as aquifer without seal layer it called unconfined aquifer.

The resistivity measurements are more likely to predict for lithologies that become an aquifer. However, the availability of water influenced by the hydrological systems as well as the water and drainage systems which are also affected by the vegetation cover on the surface and weather.

\subsection{Cross-Section 2D Resistivity}

3D resistivity section made from the cross-section between the two cross-section 2D resistivity. Crosssection is used for see how the relationship between shallow aquifer layers shown of each cross section 2D resistivity. 


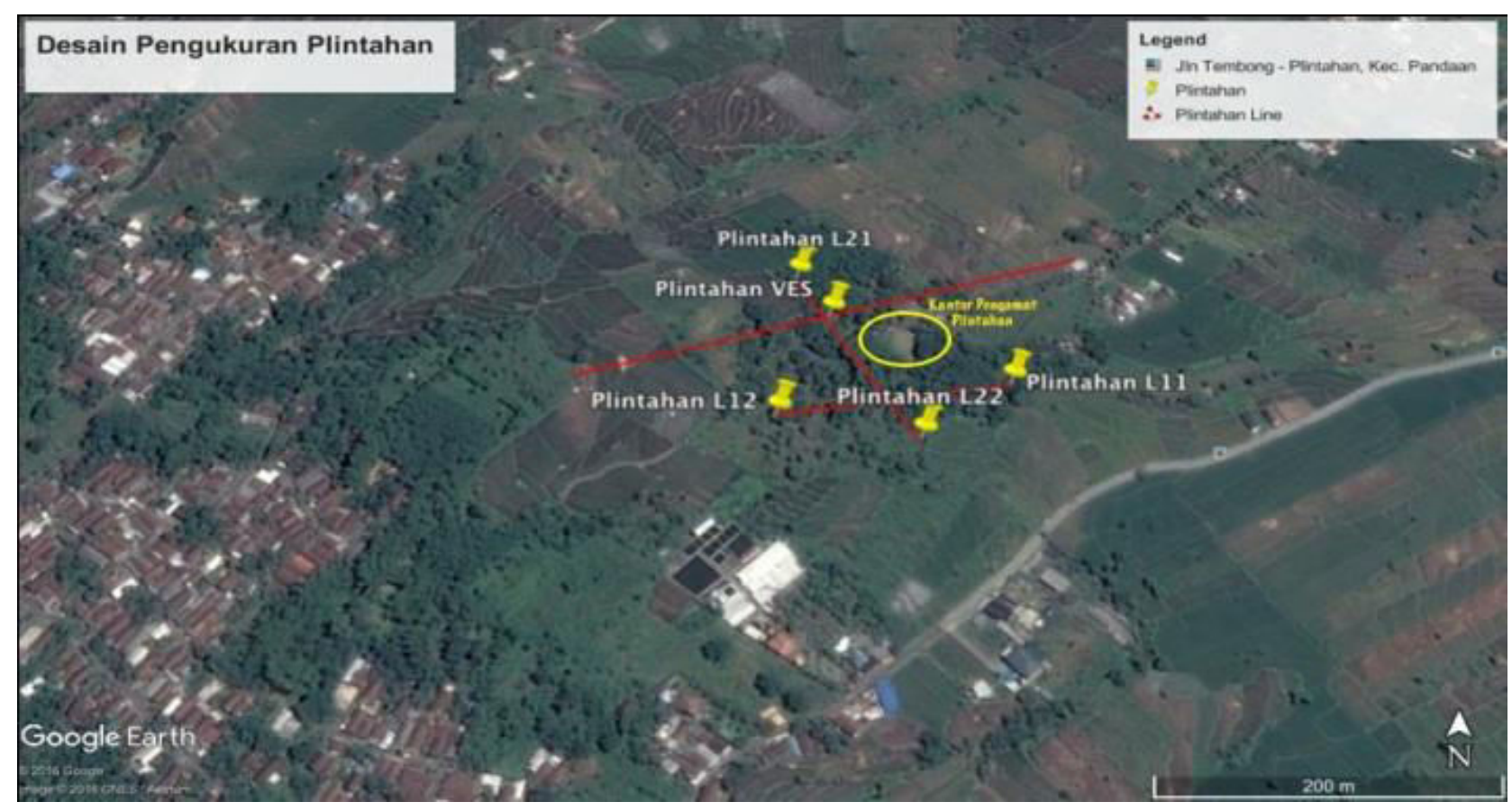

Figure 12. 2D and 1D Measurement Designs at Plintahan.

The results show that the continuity of the crosssection of the aquifer layer is not affected by the fault or fault-like structure that can make water difficult to pass trapped beneath layers that appear manifestation water source to the surface. This may result from shale lithology under it or other impermeable rocks. However, further investigations are needed to determine the subsurface features with a depth of more than 30 meters.

\subsection{Aquifer Modelling}

3D modelling used by gridding from cross-section data on groundwater aquifers. Qualitative analysis is used to predict the aquifer geometry. The results of 3D modelling can be seen each rock surface aquifer for each location. In the DurenSewu-Karangjati area shows that geometry of aquifers are not connected but there is a limiting zone. Between the two zones have similar shape and direction of distribution

Unlike the Duren sewu-Karangjati area, the aquifers located in the Plintahan area have different forms from the two zones, besides the direction of the two-zone 3D model form in the Pelintahan area in a perpendicular direction.

Based on the interpretation of the quick-look at Plintahan area has groundwater greater volume than DurensewuKarangjati area. It can be seen from the geometry of groundwater aquifers that are modeled in $3 \mathrm{D}$, because in the Plintahan area both of 2 lines make an intersection pathway and show the continuity of geometric shaped anticline structures. Different from Durensewu - Karang Jati area which has aproximate aquifer geometry an anticline but there is no continuity based on 3D modelling so that when connected with ground water content is not greater than aquifer in Plintahan. Thus the expected geometry can be used as future research in quantitative calculation of reserves with a suspected form of anticline approach in the planning of groundwater exploitation in Pasuruan for water supply of Surabaya City.

\section{CONCLUSION}

Based on data aquisition in the field and data processing, it can be concluded that the resulting 3D model shows a geometry of an aquifer has a different character. Aquifers geometry in the Plintahan show continuity with anticline geometry structure. Different with the area Durensewu - Karang Jati, which has anticline aquifer geometry prediciton but there is no continuity of the structure.

\section{AKNOWLEDGEMENTS}

Authors want to say thank you to PDAM Surya Sembada Surabaya that has supported this research by given authors permit to do data aquisition on their area. This study can not be finished well without supports from the Geophysics Exploration Laboratory of Geophysical Engineering asisstant. The authors would like to say thank you to Department of Geophysical Engineering which has provided supports so that this research can be finished well.

\section{REFERENCES}

[1] Emch, P.G. dan W.W.G. Yeh. 1998. Management Model for Conjunctive Use of Coastal Surface water and Groundwater. Journal of Water Resources Planning and Management, American Society of Civil Engineers, 124 (3), 129 
The Third International Conference on Civil Engineering Research (ICCER) August $1^{\text {st }}-2^{\text {nd }}$ 2017, Surabaya - Indonesia

[2] Fetter, C.W. 1994. Applied Hydrogeology. 3rd Ed. Merrill Publishing Company, Ohio, USA.Grigg, N.S., 1996. Water Resources Management. Mc Graw-Hill, New York, 29 - 59.

[3] Mays, L.W. 1992. Water Resources Handbook, McGraw-Hill, Singapore $6.32-6.33$.

[4] Mays, L.W. dan Y.K. Tung (1992), Hydrosystem Engineering \& Management, McGraw-Hill, Singapore, 1-20, 323-348

[5] Nemec, J. 1972. Engineering Hydrology. Mc Graw Hill. London

[6] Sosrodarsono, S. Dan K.Takeda,1993. Hidrologi Untuk Pengairan. Pradnya Paramita, Jakarta, 1-5

[7] Suripin. 2001. Pelestarian Sumberdaya Air dan Tanah. Penerbit Andi, Yogyakarta

[8] Ward, A. D. dan W. J. Elliot. 1995. Environmental Hydrology. CRC Press Inc., Florida.

[9] W. M. Telford, L. P. Geldart, R. E. Sheriff. Applied Geophysics $2^{\text {nd }}$ Edition. Cambridge University Press (1990) 283 - 292. 